\title{
Differences in nest site characteristics and hatching success in White-winged Tern (Chlidonias leucopterus) and Black Tern (Chlidonias niger)
}

\author{
Artur Golawski (i) - Emilia Mroz
}

Received: 29 March 2018/Revised: 29 September 2018/Accepted: 1 October 2018/Published online: 11 October 2018

(C) The Author(s) 2018

\begin{abstract}
Nests should be built on sites that provide optimal conditions for reproduction, so nest site characteristics are assumed to have an adaptive value. In this paper, we compared the hatching success of two species of terns: Black Tern (Chlidonias niger) (a nonexpanding species) and White-winged Tern (Chlidonias leucopterus) (an expanding species, new to the region since 1997) with respect to microhabitat nest characteristics on oxbow lakes in eastern Poland. The hatching success of White-winged Tern was lower than that of Black Tern (41.7 vs. 66.7\%). Comparison of habitat parameters at the nesting sites between the two tern species showed a significantly greater depth of water and distance from helophytes in Whitewinged Tern. Successfully hatched White-winged Tern clutches were situated much closer to the helophytes and were initiated on average up to 8 days earlier than clutches that failed to hatch. In Black Tern, hatching success was not influenced by environmental factors describing nest location. In eastern Poland, oxbow lakes are probably a suboptimal habitat and constitute an "ecological trap" for White-winged Tern; because of these suboptimal habitats, the
\end{abstract}

Handling editor: Stuart Halse

A. Golawski $(\bowtie) \cdot$ E. Mroz

Faculty of Natural Science, Siedlce University of Natural

Sciences and Humanities, Prusa 12, 08-110 Siedlce,

Poland

e-mail: artur.golawski@uph.edu.pl expansion of this species may be quite slow in predominantly dry years in eastern Poland.

Keywords Biotic factors - Expanding population · Habitat $\cdot$ Peripheral population $\cdot$ Poland

\section{Introduction}

As an aspect of habitat selection, nest site selection is assumed to have adaptive value, so nests are built on sites that provide optimum conditions for reproduction (Wiens, 1992). Several studies have shown that the selection of different nest sites can result in differences in breeding success for a given species (Chase, 2002; Doligez et al., 2002; Kruger, 2002). Many species of waders and marsh birds breed colonially; the selection of colony and nest sites thus reflects trade-offs between predation risk, flooding risk and proximity to foraging sites (O'Connell \& Beck, 2003; Borboroglu \& Yorio, 2004; Kim \& Monaghan, 2005). Birds often use indirect cues in their physical environment to guide their choice of habitat. While these can reflect current habitat quality, more often they enable individuals to anticipate the future state of the habitat. Terns from the genus Chlidonias belong to the latter type, because they tend to nest in unpredictable, impermanent locations such as marshes (Cabot \& Nisbet, 2013; Palestis, 2014), where specific 
cues, like the water level, which can be suitable at the start of the breeding season but then abruptly drop, may lead to errors in habitat selection, a phenomenon described as an "ecological trap" (Kristan, 2003; Schlaepfer et al., 2005).

It is well known that the occupation of a favourable habitat enabling high levels of reproduction and the establishment of new populations may play a major part in the spread of an expanding species (Balbontin et al., 2008; Veech et al., 2011; Ledwon et al., 2014). However, populations of species living at the edge of their range are often forced to breed in suboptimal habitats compared to their conspecifics living in the centres of their ranges (Kawecki, 2008), and the breeding success of such populations is rather low (Vucetich \& Waite, 2003; Hardie \& Hutchings, 2010). Several reasons have been suggested to explain poorer breeding output in peripheral populations, including habitat quality (Gaston, 2009). On the other hand, not much attention has been paid to the breeding biology of populations at the edges of their range that are in the process of territorial expansion, where one can expect a high production of individuals supporting the expansion (Soutullo et al., 2006; Golawski et al., 2016a).

The range of White-winged Tern (Chlidonias leucopterus Temminck, 1815) (CHL) in Europe originally covered the eastern part of the continent, with isolated sites in north-east Poland, Hungary and Romania; east-central Poland is its westernmost regular breeding site in Europe (Gochfeld et al., 2016). The last 20 years have witnessed a westward expansion of CHL in Europe: it now nests farther west in Poland, and in some wet years small colonies have been recorded even in Germany, Denmark and the Netherlands (Grell \& Rasmussen, 1997; Gruneberg \& Boschert, 2009; Ławicki et al., 2011). The number of pairs has risen markedly in eastern Poland, where the species has been breeding regularly since 1997 . At that time, just 30 pairs were reported from eastern Poland, but in some recent years the number of pairs has been in excess of 1000 (Golawski et al., 2016b). CHL is thus still a species expanding westwards, with peripheral breeding populations in eastern Poland. The typical nesting habitat of CHL is naturally waterlogged grassland (Kapocsy, 1979; Cramp, 1985; Golawski et al., 2015), but in dry seasons in eastern Poland this species has been found on oxbow lakes-permanent water bodies with floating vegetation offering potential nesting sites for terns, mainly Water Soldier (Stratiotes aloides Linnaeus, 1758) (Golawski et al., 2015). A number of differences have been found in some breeding parameters like hatching success between waterlogged grassland and oxbow lakes in Poland (Golawski et al., 2016a).

Another native species, nesting most often on the oxbow lakes in this region, is Black Tern (Chlidonias niger Linnaeus, 1758) (CHN), with a breeding population of between 480 and 650 pairs (Golawski et al., 2016b). The Black Tern's distribution range covers North America and almost the entire European continent, apart from its northern part; however, the range is not compact, especially in the western part, and has the form of isolated sites (Gochfeld \& Burger, 2016). CHL and CHN are roughly the same size, with a body weight of ca $70 \mathrm{~g}$. Both species normally lay three eggs of very similar dimensions $(35 \times 25 \mathrm{~mm})$, and both build nests of roughly the same size, i.e. ca $15 \mathrm{~cm}$ in diameter, which have to be constructed on a firm base. The eggs are incubated for around 20 days and the hatchlings fledge after ca 24 days (Cramp, 1985).

In this paper, we compare hatching success in these two species of terns with respect to the microhabitat features of nesting sites on oxbow lakes in eastern Poland. One of the species $(\mathrm{CHN})$ is native to the area, whereas the other one (CHL) began to colonise it only recently and is still in the process of expanding its range. We predicted that both tern species would achieve a similar hatching success since they nest in the same type of vegetation, mainly Water Soldier. On the other hand, since native birds are used to the conditions prevailing on the breeding grounds, they are often better at utilising resources than expanding species. Hence, one can expect birds of the former species to achieve greater breeding success than the latter, which first have to familiarise themselves with new environments (Williamson \& Fitter, 1996; Ledwon et al., 2014).

\section{Methods}

\section{Study area}

The study area lies in the valley of the River Bug near the villages of Morzyczyn and Prostyn in eastern Poland $\left(52.6667^{\circ} \mathrm{N}, 21.9002^{\circ} \mathrm{E}\right)$. This area is the 
westernmost regular breeding site of CHL in Europe; it is also a well-known permanent breeding site of CHN (Eawicki et al., 2011). The Bug is one of the largest rivers in Poland and is protected within the Natura 2000 network (number: PLB140001), with abundant breeding sites of terns (CHN and CHL; the third species of genus Chlidonias-Ch. hybrida (Pallas, 1811) was absent), including oxbow lakes (Golawski et al., 2015). Two oxbows were surveyed; they were 27 and 33 ha in area, with a maximum width of $70 \mathrm{~m}$ and a maximum depth of $1.8 \mathrm{~m}$ (Golawski et al., 2017a). About $60 \%$ of each one is covered by Water Soldier, while along their margins are 5-15 m-wide beds of rushes (Juncus sp.), Sweet Flag (Acorus calamus Linnaeus, 1758) and bulrushes (Typha sp.) forming "a wall of helophyte vegetation", growing in water as deep as $0.8-0.9 \mathrm{~m}$. Only around $30 \%$ of the oxbows are open water, usually the middle parts.

\section{Reproductive data}

The fieldwork for this study was carried out during five seasons: 2007, 2009-2010 and 2016. During this time, eight colonies of CHN and CHL were monitored. Both species breed in mixed colonies or colonies adjoining one another on the same patch of Water Soldier. Ninety-six CHL clutches and $153 \mathrm{CHN}$ clutches were monitored (CHN: mean number of nests/colony = 19.1, $\mathrm{SD}=4.7$; CHL: 12.0, SD = 3.6). Nest inspections began around 15-20 May, when the clutches were initiated and continued until early July, when the last hatchlings appeared. Since the nests were not fenced in, the fates of fledglings leaving the nest after a few days were not tracked. As a rule, visits to nests took place once a week, but in the period when hatching was expected, they were monitored every 3-4 days. The nest inspection dates were chosen so as to include the hatching peak: this was calculated from the estimated laying date and the average incubation period of 20 days, assuming that eggs were laid at 1-day intervals (Cramp, 1985). Most of the nests were found during the egg-laying period or at the beginning of incubation, so it was possible to determine the hatching date of nestlings accurate to \pm 1 day. Clutch initiation dates were calculated with a similar accuracy. For determining the hatching date, body mass measurements of nestlings in or right beside the nest were used; these figures were then compared with those of nestlings of known hatching date. Every year the first inspection involved searching for nests in the whole or part (in colonies with more than 30 breeding pairs; two colonies) of the breeding colony. In the biggest colonies, the nests found in a 5-m-wide belt of Water Soldier were monitored. Such a belt was selected at random, but always in such a way that it began in the middle of a patch of Water Soldier and ended at the edge of that patch, which coincided with the bank of the oxbow lake. During every inspection in the season, the observer moved along this belt, monitoring all the clutches that appeared in the course of the season. For this purpose, an inflatable dinghy was used to gain access to the nests on the oxbows. Inspection of one colony lasted a maximum of $1 \mathrm{~h}$ and was conducted only during favourable weather (no precipitation, temperature $>22^{\circ} \mathrm{C}$ ). The positions of the nests were mapped, and a marker was placed in the field near each one. The causes of total losses were grouped into three categories: losses due to inclement weather, predation and unknown causes. Depredation was considered to have been the cause if the eggs were found smashed, probably by corvids Corvidae or mammalian predators, or if the nest was found empty before the presumed hatching date. Clutches were considered lost as a result of inclement weather when nests or the Water Soldier they were on was flooded or the clutch had been blown off the nest. The cause(s) of failure of some nests could not be established. A successful clutch was one that produced at least one hatchling, which was observed on or near the nest: the chicks remain close to the nest for a few days after hatching (Cramp, 1985; personal observations).

\section{Habitat measurements}

During the first or second inspection of the colony, habitat parameters were measured where nests had been built. These parameters were chosen on the basis of papers dealing with habitat selection in Chlidonias terns (Paillisson et al., 2006; Maxson et al., 2007). They were as follows: (1) water depth to the hard bottom (cm); (2) distance of the nest from the wall of helophytes (m); (3) coverage of floating vegetation (mainly Water Soldier) within a 2-m radius of the nest (\%); (4) coverage of helophytes (mainly sweet flag and rushes) within a 2-m radius of the nest (\%); (5) height of vegetation above water level within a $0.2-\mathrm{m}$ radius of the nest-mean of four measurements made in the principal compass directions $(\mathrm{cm})$. These parameters 
were measured for all nests found in accordance with the above scheme.

Statistical analysis

A general linear mixed model (GLMM) was constructed to test the effects of parameters describing nest location on hatching success in two tern species. To reduce any effects of multicollinearity, pairs of habitat variables were tested for correlation using Spearman's rank correlation test (Sokal \& Rohlf 1995). If two variables were highly correlated $\left(r_{\mathrm{s}-}\right.$ $>0.60$, Mertler \& Vannatta, 2002), only one data set was selected (one factor was removed- "the percentage of floating macrophyte species $2 \mathrm{~m}$ around the nest"; "the percentage of helophyte vegetation $2 \mathrm{~m}$ around the nest" was retained). In consequence, every GLMM analysis covered the following parameters describing nest location, modelled as fixed effects: (1) water depth, (2) distance of the nest from the wall of helophytes, (3) coverage (\%) of helophytes within a $2-\mathrm{m}$ radius of the nest, (4) height of the vegetation surrounding the nest. IDs (numbers from 1 to 8 ) were assigned to colonies according to the order in which they were inspected; they were random factors in all the GLMM analyses. The first analysis compared parameters describing the nest sites of both tern species, with species being treated as response variables. The second and third analyses compared nest site parameters with hatching success or failure (response variables), again separately for the two tern species. Since all the clutches/broods were monitored from the egg-laying stage, Mayfield's method for estimating nest survival when nests are found at different stages of clutch/brood advancement was not used. In the last two analyses, the clutch initiation date (the first-egg-laying date) was taken to be a covariate, since it can have a considerable influence on the success or failure of a tern clutch (Golawski et al., 2017b). GLMM with logit-link function and binomial error variance was used in each analysis.

Akaike's information criterion (AIC, Akaike, 1973) corrected for small samples (AICc) was used to determine the model that best explained the variation in the data. Models were ranked in relation to each other using $\Delta \mathrm{AIC}_{\mathrm{c}}$ values, where $\Delta_{\mathrm{i}}=\mathrm{AIC}_{\mathrm{c}(\mathrm{i})-}$ $-\mathrm{AIC}_{\mathrm{c}(\text { min) })}$. We considered models with $\Delta \mathrm{AIC}_{\mathrm{c}}<2$ as equally good and consequently as having the highest Akaike weight $\left(\omega_{\mathrm{i}}\right)$ (Burnham \& Anderson, 2002).

The difference between the hatching successes of the two tern species was assessed using the $\chi^{2}$ test, with values being reported as mean \pm 1 SE. Only results with a probability of $\alpha \leq 0.05$ were assumed to be statistically significant. All statistics were performed in SPSS version 21.0. for Windows (SPSS Inc., 2012) and Statistica 10.0 (StatSoft, 2012).

\section{Results}

Hatching success and nest losses

The hatching success of CHN was $66.7 \%(n=153$ clutches) and that of CHL was $41.7 \% \quad(n=96$ clutches); the difference in this parameter between the species was statistically significant (Yates corrected $\left.\chi^{2}=14.04, \mathrm{df}=1, P<0.001\right)$. In CHN 80.4\% of clutches failed because of the weather conditions (nests became submerged or moved by wind and abandoned by the birds), whereas in CHL this was the cause of as many as $91.1 \%$ of all clutch losses (Fig. 1). Predation was responsible for $9.8 \%$ of losses in CHN and $1.8 \%$ in CHL. The causes of clutch losses did not differ significantly between the two species $\left(\chi^{2}=3.64, \mathrm{df}=2, P=0.162\right)$.

\section{Differences in habitat use between species}

Only one best model including all the covariates predicted differences in habitat use between the two tern species (Table 1). Comparison of habitat parameters at the nesting sites between the two tern species showed a significantly greater depth of water and distance from the wall of helophytes in CHL, whereas the proportion of helophytes and their height near the nest did not differ significantly (Tables 2, 3). Also significantly different were the average first-egglaying dates: 9 days earlier in CHN than in CHL (20 May vs. 29 May).

Habitat parameters and hatching success

Six models best predicted habitat differences between clutches with and without hatching success in CHN (Table 1), but none of the parameters turned out to be statistically significant (Table 3 ); the clutch initiation 

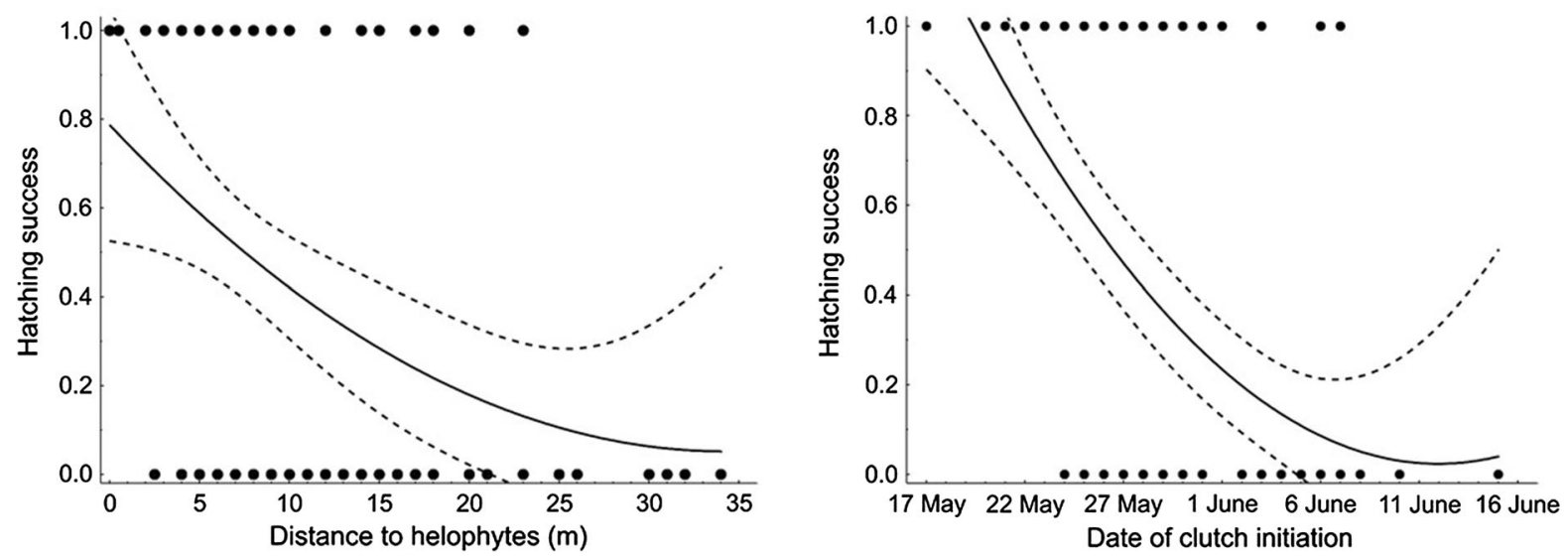

Fig. 1 Probability of hatching success of White-winged Tern ( $n=96$ clutches) in relation to the distance of nest to the "helophyte zone" and clutch initiation date. The dashed lines correspond to the $95 \%$ confidence interval

Table 1 Top-supported models describing the differences in habitat use between two tern species and for clutches with and without hatching success in two tern species

\begin{tabular}{|c|c|c|c|c|}
\hline Model & $K$ & $\mathrm{AIC}_{\mathrm{c}}$ & $\Delta \mathrm{AIC}_{\mathrm{c}}$ & $\omega_{\mathrm{i}}$ \\
\hline \multicolumn{5}{|l|}{ Difference in habitat use between two tern species } \\
\hline Water + zone + plant height + helophytes $\%$ & 5 & 251.783 & 0 & 0.827 \\
\hline \multicolumn{5}{|c|}{ Difference in habitat use for clutches with and without hatching success in Black Tern } \\
\hline Zone & 2 & 197.599 & 0 & 0.170 \\
\hline Plant height & 2 & 198.211 & 0.612 & 0.125 \\
\hline Helophytes \% & 2 & 198.714 & 1.116 & 0.097 \\
\hline Water & 2 & 198.734 & 1.136 & 0.096 \\
\hline Zone + helophytes $\%$ & 3 & 199.094 & 1.495 & 0.081 \\
\hline Zone + plant height & 3 & 199.154 & 1.555 & 0.078 \\
\hline \multicolumn{5}{|c|}{ Difference in habitat use for clutches with and without hatching success in White-winged Tern } \\
\hline Zone + plant height & 3 & 109.904 & 0 & 0.486 \\
\hline Zone + plant height + helophytes $\%$ & 4 & 111.657 & 1.752 & 0.202 \\
\hline Water + zone + plant height & 4 & 111.792 & 1.887 & 0.189 \\
\hline
\end{tabular}

The number of parameters in a model $(K)$, the Akaike information criterion score $\left(\mathrm{AIC}_{\mathrm{c}}\right)$, the difference between the given model and the most parsimonious model $\left(\Delta \mathrm{AIC}_{\mathrm{c}}\right)$, and the Akaike weight $\left(\omega_{\mathrm{i}}\right)$ are listed; zone nest distance to "helophyte zone", helophytes \% $\%$ of helophytes $2 \mathrm{~m}$ around the nest, water water depth under the nest, plant height height of vegetation $20 \mathrm{~cm}$ around the nest

Table 2 Mean and SE of variables at nesting sites of Black Tern and Whitewinged Tern

\begin{tabular}{|c|c|c|c|c|}
\hline \multirow[t]{2}{*}{ Variable } & \multicolumn{2}{|c|}{$\begin{array}{l}\text { Black Tern } \\
n=153\end{array}$} & \multicolumn{2}{|c|}{$\begin{array}{l}\text { White-winged Tern } \\
n=96\end{array}$} \\
\hline & Mean & SE & Mean & $\mathrm{SE}$ \\
\hline Water depth $(\mathrm{cm})$ & 90.0 & 1.7 & 109.6 & 2.0 \\
\hline Helophyte vegetation $2 \mathrm{~m}$ around the nest (\%) & 4.6 & 0.7 & 1.3 & 0.5 \\
\hline Floating macrophytes $2 \mathrm{~m}$ around the nest (\%) & 61.7 & 2.0 & 68.4 & 1.4 \\
\hline Height of plants $20 \mathrm{~cm}$ around the nest $(\mathrm{cm})$ & 9.3 & 0.3 & 10.2 & 0.8 \\
\hline Nest distance to "helophyte zone" (m) & 5.8 & 0.3 & 13.8 & 0.8 \\
\hline
\end{tabular}


Table 3 Factors affecting difference in habitat use and hatching success in Black Tern and White-winged Tern
Statistically significant relationships are shown in bold. The random effect (colony ID) is not statistically significant in all cases

\begin{tabular}{lcccr}
\hline Effect & Estimate & SE & $t$ & $P$ \\
\hline Difference in habitat use between two species of terns & & & \\
Water depth & -0.072 & 0.018 & -3.94 & $<\mathbf{0 . 0 0 1}$ \\
Helophyte vegetation 2 m around the nest & 0.091 & 0.078 & 1.16 & 0.248 \\
Height of plants $20 \mathrm{~cm}$ around the nest & -0.153 & 0.057 & -1.69 & 0.080 \\
Distance from nest to "helophyte zone" & -0.209 & 0.064 & -3.28 & $\mathbf{0 . 0 0 1}$ \\
Clutch initiation date & -0.238 & 0.049 & -4.82 & $<\mathbf{0 . 0 0 1}$ \\
Difference in habitat use for clutches with and without hatching success in Black Tern \\
Water depth & 0.003 & 0.012 & 0.27 & 0.786 \\
Helophyte vegetation 2 m around the nest & 0.093 & 0.032 & 1.79 & 0.074 \\
Height of plants $20 \mathrm{~cm}$ around the nest & -0.094 & 0.052 & -1.78 & 0.076 \\
Distance from nest to "helophyte zone" & 0.062 & 0.060 & 1.04 & 0.299 \\
Clutch initiation date & 0.018 & 0.040 & 0.453 & 0.651 \\
Difference in habitat use for clutches with and without hatching success & in White-winged Tern \\
Water depth & 0.008 & 0.037 & 0.22 & 0.830 \\
Helophyte vegetation 2 m around the nest & -0.368 & 0.302 & -1.22 & 0.226 \\
Height of plants 20 cm around the nest & -0.008 & 0.095 & -0.08 & 0.936 \\
Distance from nest to "helophyte zone" & 0.160 & 0.060 & 2.66 & $\mathbf{0 . 0 0 9}$ \\
Clutch initiation date & 0.193 & 0.081 & 2.39 & $\mathbf{0 . 0 1 9}$ \\
\hline
\end{tabular}

date in these two categories did not differ either (20 May vs. 23 May). For CHL, three models best predicted habitat differences between clutches with and without hatching success (Table 1). Clutches successfully hatched were situated much closer to the wall of helophytes (Fig. 2) and were initiated on average up to 8 days earlier compared with those that failed to hatch (25 May vs. 2 June, Fig. 2). The other parameters did not significantly differentiate the two clutch categories (Table 3).

\section{Discussion}

Hatching success and nest losses

CHN, native in eastern Poland, achieved a far superior hatching success to $\mathrm{CHL}$, which did not become a regular breeder in this area until 20 years ago (Golawski et al., 2016b). Since both species nested in the same patches of vegetation on the same oxbow, this result is surprising. The causes of clutch losses in both species were similar, but the issues of weather significance need to be considered in greater detail. In our opinion, the key weather factor responsible for the destruction of clutches was heavy rain causing the water level in the oxbows to rise. The nests were built on the leaves of Water Soldier. But as this is a floating plant, a water level rise should not in theory pose any danger to the clutches. Nonetheless, it was observed that after a water level rise of just a few $\mathrm{cm}$ during 3-4 days, the eggs in the nests had become waterlogged. This suggests that during a slight but rapid rise in water level, Water Soldier plants lose their rigidity and are no longer capable of supporting the nest and eggs above water. The second weather factor negatively influencing clutches was strong winds and wave action during thunderstorms. They perished while clumps of Water Soldier were being pushed around the oxbow, which caused the birds to abandon their nests (Golawski et al., 2017b).

The abandonment of nests by parent birds could have been also elicited by, for example, the presence of researchers nearby (during our surveys birds quickly returned to their nests when we were about $15 \mathrm{~m}$ away), but bad weather cannot be ruled out altogether. Studies of terns from the Chlidonias genus in North America and Poland have shown that inspections of clutches rarely lead to their abandonment (Shealer \& Haverland, 2000; Ledwon et al., 2015), and disturbance by third parties, like anglers, did not occur in eastern Poland because the banks of the oxbows were accessible only with great difficulty. 
It is worth noting here that the danger to nests from predators is relatively small: only 6 of 249 clutches were robbed $(2.4 \%)$. These natural nesting sites on Water Soldier floating on water around $100 \mathrm{~cm}$ deep are thus safe. Although North American populations of $\mathrm{CHN}$ were much more exposed to predation pressure, the most important cause of nest losses, as in eastern Poland, was bad weather (Shealer \& Haverland, 2000; Shealer et al., 2006). In contrast, $30 \%$ of eastern Polish populations of CHL nesting in waterlogged sedge fields were affected by predation (Golawski et al., 2016a), like their counterparts in Siberia (Melnikov, 1977).

Difference in habitat use between species and hatching success

Direct comparison of the nest sites of the two tern species showed CHN to be nesting closer to the wall of helophytes and on shallower water. CHL thus built its nests closer to the centre of the patches of vegetation (mainly Water Soldier) than CHN, which in turn more often chose the edge of such patches, on the borderline with the helophytes. No detailed studies of microhabitat preferences in CHL are known to have been carried out (Golawski et al., 2015), but such preferences have been described for CHN, in considerable detail for its populations inhabiting North America and western Europe (Hickey \& Malecki, 1997; Van der Winden et al., 2004; Maxson et al., 2007), and the habitat preferences were similar to those described in eastern Poland.

The literature gives no information on reproductive parameters of CHL in different habitats of the core breeding range, and in general the data on this species are very scarce (Melnikov, 1977; Kapocsy, 1979). The positioning of nests was reflected in the survival of clutches until hatching, although this only applied to CHL. Clutches laid closer to the wall of helophytes enjoyed a superior hatching success. CHL thus preferred to nest nearer the centre of Water Soldier patches, but clutches had a better chance of survival nearer the edge of these patches, i.e. closer to the edge of the oxbow. The distribution of all nests in large tern colonies was not monitored as this was physically impossible-moving around over the Water Soldier plants is arduous and time-consuming and would endanger the terns. Very probably, however, the sites in the centres of the Water Soldier patches preferred by
CHL were also the centre of breeding colony. It has been frequently demonstrated that the colony centre is the safest place for nesting terns because the level of predation is lower (Yorio \& Quintana, 1997; Minias et al., 2013). As far as CHL in eastern Poland is concerned, the nests at the edge of the colony survived better than those at the centre. Their fate was dependent on the weather conditions and not on predation. Breeding success may differ between centre and edge nests because of such factors like colony accessibility, food supply, nesting density and quality of birds (Brunton, 1997; Minias et al., 2013). To this list one can add weather conditions.

Clutch initiation date was a significant factor in the achievement of hatching success by CHL; clutches that hatched were laid on average 8 days earlier than those that were lost. It is worth adding that successfully hatched $\mathrm{CHN}$ clutches were laid on average 3 days earlier than those that failed to do so, although this was not a statistically significant difference. In North America likewise, clutches laid earlier had a better chance of hatching, but concealment of the nest from predators was also important (Laurel, 1999). In eastern Poland, where predation is marginal, concealment by vegetation played no part in the achievement of hatching success by CHN. Differences in hatching success were due to the phenology of the weather conditions, i.e. heavy rainfall and strong winds, probably accompanying thunderstorms (Golawski et al., 2017b). Such bad weather was more frequent in June and July, so clutches laid later suffered more as a result. These conditions were not only of great importance to $\mathrm{CHL}$ clutches; they were primarily responsible for the differences in breeding success between $\mathrm{CHL}$ and $\mathrm{CHN}$, as the latter started breeding on average 9 days earlier than the former, probably because of its earlier return from its wintering grounds (Golawski et al., 2017b). High winds and strengthening wave action caused the Water Soldier in the centres of patches to move considerable distances-as far as $350 \mathrm{~m}$ in extreme cases, and then clutch destruction was inevitable. In contrast, the severalmetre-wide belt of Water Soldier by the edge of the oxbow remained in place: the taller helophyte vegetation gave shelter from wind and waves, thus preventing it from floating away. This was reflected by superior clutch survival in these places. This dependence applied mainly to CHL, since the majority of earlier nesting $\mathrm{CHN}$ already had chicks at this time, 
so we interpreted these clutches as having hatched. Since tern chicks remain in the nest for just a few days after hatching (Cramp, 1985), most CHN chicks will have survived bad weather periods affecting nests since they were no longer in them.

Why does CHL choose less secure sites for nesting?

Two reasons for this behaviour need to be considered. First of all, CHL adopts the classical strategy, whereby clutches in the colony centre should achieve the greatest success. But since the prime cause of clutch losses is bad weather, this strategy turns out to be ineffective. It is effective as a way of counteracting predation pressure (Yorio \& Quintana, 1997; Minias et al., 2013), but, as the present study has shown, this is not too serious in eastern Poland. This behaviour may be due to the inexperience of CHL in selecting nest sites in newly colonised areas, in habitats that are not typical for this species (Melnikov, 1977; Cramp, 1985; Golawski et al., 2016a). This is confirmed by the different preferences for habitats, safer ones as it turns out, by CHN, which has been breeding in eastern Poland for many years (Golawski et al., 2016b). In eastern Poland, therefore, CHL would thus fall into an "ecological trap": in accordance with the assumptions underlying this concept, CHL selects poor quality habitat rather than available higher quality habitat and suffers from reduced fitness in the preferred habitat (Donovan \& Thompson, 2001). The second possibility, far less probable in our opinion, is competition with $\mathrm{CHN}$ for the best nesting sites. Since CHN arrives back in eastern Poland much earlier than CHL, it chooses the best sites for building nests adjacent to the wall of helophytes, which guarantees the nests greater security. CHL is thus forced to nest farther away from the helophyte wall, which is why it suffers greater clutch losses. These greater losses are exacerbated by thunderstorms, which become more frequent and fiercer as the terns' breeding season progresses (Golawski et al., 2017b). It appears to us, moreover, that there are many suitable sites for nesting in the Water Soldier patches in the oxbows that the laterarriving CHLs could occupy. But then again, the decisions taken by the terns do not necessarily have to correspond to the preferences we have stated.

In Europe, CHL is very slowly expanding westwards (Gruneberg \& Boschert, 2009; Ławicki et al.,
2011), and this is probably due to insufficient suitable habitat. In Poland, on the one hand, CHL very definitely prefers to nest in waterlogged sedge fields, but on the other, seasons when high water inundates these fields occur only once every few years (Golawski et al., 2015). Then, numbers of CHL can be many times higher than in drier years (Ławicki et al., 2011). In these drier years, smaller numbers of CHL nest in suboptimal habitats, i.e. on oxbows, where breeding success is poor. Perhaps, due to the occurrence of suboptimal habitats in predominantly dry years, the expansion of this species is quite slow. Similar relationships have been demonstrated in other aquatic birds (e.g. Pyk et al., 2013). By contrast, the population of $\mathrm{CHN}$ in this region, successfully breeding there, has been stable for many years (Golawski et al., 2017b).

Acknowledgements We would like to thank Zbigniew Kasprzykowski, Ewa Dros and Pawel Zminczuk for carrying out the surveys, and we are grateful to Peter Senn for the translation and English language editing. We are also grateful to the anonymous reviewers for their critical remarks. The results of the research carried out as part of the research topic No. 75/94/s were financed from the science grant awarded by the Ministry of Science and Higher Education".

Open Access This article is distributed under the terms of the Creative Commons Attribution 4.0 International License (http:// creativecommons.org/licenses/by/4.0/), which permits unrestricted use, distribution, and reproduction in any medium, provided you give appropriate credit to the original author(s) and the source, provide a link to the Creative Commons license, and indicate if changes were made.

\section{References}

Akaike, H., 1973. Information theory as an extension of the maximum likelihood principle. In Petrov, B. N. \& F. Csaki (eds), Second International Symposium on Information Theory. Akademiai Kiado, Budapest.

Balbontin, J. J., J. Negro, J. H. Sarasola, J. J. Ferrero \& D. Rivera, 2008. Land-use changes may explain the recent range expansion of the Black-shouldered Kite Elanus caeruleus in southern Europe. Ibis 150: 707-716.

Borboroglu, P. G. \& P. Yorio, 2004. Habitat requirements and selection by kelp gulls (Larus dominicanus) in central and northern Patagonia, Argentina. Auk 121: 243-252.

Brunton, D. H., 1997. Impacts of predators: center nests are less successful than edge nests in a large nesting colony of Least Terns. Condor 99: 372-380.

Burnham, K. P. \& D. R. Anderson, 2002. Model Selection and Multimodel Inference. Springer, New York. 
Cabot, D. \& I. Nisbet, 2013. Terns. Harper Collins, London.

Chase, M. K., 2002. Nest site selection and nest success in a song sparrow population: the significance of spatial variation. Condor 104: 103-116.

Cramp, S., 1985. The Birds of the Western Palearctic, Vol. 4. Oxford University Press, Oxford.

Doligez, B., E. Danchin \& J. Clobert, 2002. Public information and breeding habitat selection in a wild bird population. Science 297: 1168-1170.

Donovan, T. M. \& F. R. Thompson, 2001. Modeling the ecological trap hypothesis: a habitat and demographic analysis for migrant songbirds. Ecological Applications 11: 871-882.

Gaston, K. J., 2009. Geographic range limits of species. Proceedings of the Royal Society of London B 276: 1391-1393.

Gochfeld, M. \& J. Burger, 2016. Black Tern (Chlidonias niger). In del Hoyo, J., A. Elliott, J. Sargatal, D. A. Christie \& E. de Juana (eds), Handbook of the birds of the World Alive. Lynx Edicions, Barcelona. http://www.hbw.com/node/ 54047.

Gochfeld, M., J. Burger, D. A. Christie \& G. M. Kirwan, 2016. White-winged Tern (Chlidonias leucopterus). In del Hoyo, J., A. Elliott, J. Sargatal, D. A. Christie \& E. de Juana (eds), Handbook of the birds of the World Alive. Lynx Edicions, Barcelona. http://www.hbw.com/node/54047.

Golawski, A., Z. Kasprzykowski, E. Mroz, M. Rzepala \& S. Chmielewski, 2015. The differences in habitat selection in two sympatric species of eastern Poland: the White-winged Tern (Chlidonias leucopterus) and the Black Tern (Chlidonias niger). Wilson Journal of Ornithology 127: 52-58.

Golawski, A., Z. Kasprzykowski, M. Ledwon, E. Mroz \& F. Morelli, 2016a. Brood sex-ratio in expansive and non-expansive tern species in east-central Poland. Bird Study 63: 31-36.

Golawski, A., E. Mroz \& Z. Kasprzykowski, 2016b. Breeding performance of the White-winged Tern (Chlidonias leucopterus) in two habitat types at the edge of their distribution range. Ornis Fennica 93: 225-234.

Golawski, A., I. Hajdamowicz \& S. Golawska, 2017a. Macroinvertebrate occurrence in Chlidonias niger (Charadriiformes: Laridae) nests in east-central Poland. Journal of Entomological Science 52: 288-292.

Golawski, A., Z. Kasprzykowski \& E. Mroz, 2017b. Wind differentiates reproduction in the non-expansive Black Tern Chlidonias niger and the expansive White-winged Tern Chlidonias leucopterus. Aquatic Ecology 51: 235-245.

Grell, M. \& L. M. Rasmussen, 1997. First breeding of the whitewinged black tern in Denmark. Dansk Ornitologisk Forenings Tidsskrift 91: 121-124.

Gruneberg, C. \& M. Boschert, 2009. Weißbart- und Weißflügelseeschwalben in Deutschland: Bestandsentwicklung und aktuelle Brutverbreitung. DDA-Monitoring-Rundbrief 1: 9-13.

Hardie, D. C. \& J. A. Hutchings, 2010. Evolutionary ecology at the extremes of species' ranges. Environmental Review 18: $1-20$.

Hickey, J. M. \& R. A. Malecki, 1997. Nest site selection of the Black Tern in western New York. Colonial Waterbirds 20: 582-595.
IBM Corp Released, 2012. IBM SPSS Statistics for Windows, Version 21.0. IBM Corp, Armonk.

Kapocsy, G., 1979. Weißflügel- und Weißartseechwalbe. A Ziemsen Verlag, Wittenberg.

Kawecki, T. J., 2008. Adaptations to marginal habitats. Annual Review of Ecology, Evolution, and Systematics 39: 321-342.

Kim, S.-Y. \& P. Monaghan, 2005. Effects of vegetation on nest microclimate and breeding performance of lesser blackbacked gulls (Larus fuscus). Journal of Ornithology 146: 176-183.

Kristan III, W. B., 2003. The role of habitat selection behavior in population dynamics: source-sink systems and ecological traps. Oikos 103: 457-468.

Kruger, O., 2002. Analysis of nest occupancy and nest reproduction in two sympatric raptors: common buzzard Buteo buteo and goshawk Accipiter gentilis. Ecography 25: 523-532.

Laurel, B. J., 1999. Habitat selection and breeding success of black terns (Chlidonias niger) in impounded wetlands in New Brunswick. Dissertation, University of New Brunswick.

Ławicki, Ł., S. Niedźwiecki, W. Sawicki, et al., 2011. Numerous nesting of the White-winged Tern Chlidonias leucopterus in Poland in 2010. Ornis Polonica 52: 85-96.

Ledwon, M., J. Betleja, T. Stawarczyk \& G. Neubauer, 2014. The Whiskered Tern Chlidonias hybrida expansion in Poland: the role of immigration. Journal of Ornithology 155: 459-470.

Ledwon, M., J. Betleja \& G. Neubauer, 2015. An effective method for trapping both parents and chicks of Whiskered Terns (Chlidonias hybrida) and its impact on breeding success. Waterbirds 38: 290-295.

Maxson, S. J., J. R. Fieberg \& M. R. Riggs, 2007. Black Tern nest habitat selection and factors affecting nest success in Northwestern Minnesota. Waterbirds 30: 1-9.

Melnikov, J. I., 1977. Ecology of White-winged Tern in eastern Siberia. In Skryabin, N. G. (ed.), Ecology of Birds in Eastern Siberia, Irkutsk. Irkutsk University Publication, Irkutsk.

Mertler, C. A. \& R. A. Vannatta, 2002. Advanced and Multivariate Statistical Methods: Practical Application and Interpretation. Pyrczak Publishing, Los Angeles.

Minias, P., T. Janiszewski \& B. Lesner, 2013. Center-periphery gradients of chick survival in the colonies of Whiskered Terns Chlidonias hybrida may be explained by the variation in the maternal effects of egg size. Acta Ornithologica 48: 179-186.

O’Connell, T. J. \& R. A. Beck, 2003. Gull predation limits nesting success of terns and skimmers on the Virginia barrier islands. Journal of Field Ornithology 74: 66-73.

Paillisson, J.-M., S. Reeber, A. Carpentier \& L. Marion, 2006. Plant-water regime management in a wetland: consequences for a floating vegetation-nesting bird, whiskered tern Chlidonias hybrida. Biodiversity and Conservation 15: 3469-3480.

Palestis, B. G., 2014. The role of behavior in tern conservation. Current Zoology 60: 500-514.

Pyk, T. M., M. A. Weston, A. Bunce \& F. I. Norman, 2013. Establishment and development of a seabird colony: long term trends in phenology, breeding success, recruitment, 
breeding density and demography. Journal of Ornithology 154: 299-310.

Schlaepfer, M. A., P. W. Sherman, B. Blossey \& M. C. Runge, 2005. Introduced species as evolutionary traps. Ecology Letters 8: 241-246.

Shealer, D. A. \& J. A. Haverland, 2000. Effects of investigator disturbance on the reproductive behavior and success of Black Terns. Waterbirds 23: 15-23.

Shealer, D. A., J. M. Buzzell \& J. P. Heiar, 2006. Effect of floating nest platforms on the breeding performance of Black Terns. Journal of Field Ornithology 77: 184-194.

Sokal, R. R. \& F. J. Rohlf, 1995. Biometry, 3rd ed. WH Freeman and Company, New York.

Soutullo, A., R. Liminana, V. Urios, M. Surroca \& J. A. Gill, 2006. Density-dependent regulation of population size in colonial breeders: allee and buffer effects in the migratory Montagu's harrier. Oecologia 149: 543-552.

StatSoft Inc., 2012. Statistica, data analysis software system, version 10.0. www.statsoft.com.
Van der Winden, J., A. J. Beintema \& L. Heemskerk, 2004. Habitat-related Black Tern Chlidonias niger breeding success in The Netherlands. Ardea 92: 53-61.

Veech, J. A., M. F. Small \& J. T. Baccus, 2011. The effect of habitat on the range expansion of a native and an introduced bird species. Journal of Biogeography 38: 69-77.

Vucetich, J. A. \& T. A. Waite, 2003. Spatial patterns of demography and genetic processes across the species' range: null hypotheses for landscape conservation genetics. Conservation Genetics 4: 639-645.

Wiens, J. A., 1992. The Ecology of Bird Communities, Vol. 1. Cambridge University Press, Cambridge.

Williamson, M. H. \& A. Fitter, 1996. The varying success of invaders. Ecology 77: 1661-1666.

Yorio, P. \& F. Quintana, 1997. Predation by Kelp Gulls Larus dominicanus at a mixed-species colony of Royal Terns Sterna maxima and Cayenne Terns Sterna eurygnatha in Patagonia. Ibis 139: 536-541. 